\title{
PERANCANGAN TRAINER MIKROKONTROLER SEBAGAI MEDIA PEMBELAJARAN UNTUK MENINGKATKAN NILAI PADA MATA PELAJARAN PEREKAYASAAN SISTEM KONTROL PADA SMK
}

\author{
Febriana Suryania, Moch. Sukardjo, M.Yusro \\ Universitas Negeri Jakarta, Indonesia \\ Email: fsuryania.pambudi@gmail.com
}

\begin{abstract}
ABSTRAK
Perubahan kurikulum dari KTSP menjadi kurikulum 2013 mengakibatkan perubahan mata pelajaran, jam mata pelajaran, serta penambahan jam mata pelajaran yang mempengaruhi perubahan dari sebuah literasi, yaitu siswa yang selalu diberi tahu menjadi siswa yang mencari tahu. Perubahan kurikulum pada proses pembelajaran dikelas maupun diluar kelas akan mengakibatkan proses penilaian yang berawal hanya berbasis output menjadi berbasis proses dan output. Untuk itu sarana prasarana harus dapat menunjang proses pembelajaran, maka peneliti merancang alat berupa trainer mikrokontroler sebagai media pembelajaran untuk meningkatkan kemampuan siswa dalam proses belajar. Penelitian ini menggunakan R\&D dengan metode ADDIE dan Borg \& Gall sebagai penelitian pendahuluan. Penelitian dilakukan di SMK Teknik Elektronika Industri, dengan jumlah responden 31 siswa yang akan mengambil mata pelajaran perekayasaan sistem kontrol dengan melihat nilai kognitif dan psikomotor sebagai hasil peningkatan siswa. Penilaian menggunakan tes pilihan ganda yang sudah divalidasi terlebih dahulu dan kemudian diujikan kepada siswa dengan membandingkan antara nilai pretest dan posttest. Kemudian, penelitian ini menggunakan uji-t sebagai perhitungan dalam mengetahui tingkat efektifitas belajar baik secara kognitif maupun psikomotor. Hasil nilai kognitif menyimpulkan bahwa ada peningkatan nilai yang dihasilkan, sedangkan nilai pada psikomotor menyimpulkan bahwa siswa terampil dalam mengoperasikan trainer mikrokontroler dengan melihat hasil praktikum. Trainer mikrontroler ini dapat dikembangkan kembali baik dari segi chip, input maupun output dan dapat diaplikasikan pada pengembangan alat kerja.
\end{abstract}

Kata Kunci: Media Pembelajaran; Trainer Mikrokontroler; Peningkatan Nilai

\begin{abstract}
Changes in the curriculum from KTSP to the 2013 curriculum resulted in changes of subjects, hours of subjects, as well as additional hours of subjects that affect changes in mindset from students who are told to students who find out. Changes in the curriculum in the learning process in classroom and outside the classroom will result in an assessment process that begins only based on output to be process-based and output-based. For that reason, facilities and infrastructure must be able to support the learning process. The researchers designed a tool in the form of a microcontroller trainer as a learning medium to improve students' abilities in the learning process. This research employs R \& D (Research and Development) with the ADDIE and Borg \& Gall methods as preliminary studies. The research was conducted at Industrial Electronics Engineering Vocational School, with 31 students as respondent who enroll the system engineering subjects by looking at the increasing of cognitive and psychomotor values. The assessment uses a multiple choice test that has been validated and then tested on students by comparing the value of the pre-test and post-test. Then, this research employs the t-test as a calculation in knowing the level of effectiveness of learning both cognitive and psychomotor. The results of cognitive values conclude that there is an increase in the score, while the psychomotor value finds that students are skilled in operating the microcontroller trainer by looking at the results of the lab. This
\end{abstract}


microcontroller trainer can be developed both in terms of chips, inputs, and outputs and can be applied to the development of work tools.

Keywords: Learning media, Microcontroller Trainer, increase in value

\section{PENDAHULUAN}

Salah satu permasalahan yang terjadi pada sekolah yaitu perubahan kurikulum. Kurikulum KTSP berubah menjadi kurikulum 2013 yang mengakibatkan perubahan struktur mata pelajaran. Kurikulum berdampak pada sub materi pelajaran yang berubah dan sarana prasarana yang berkembang mengikuti perubahan kurikulum tersebut. Konten materi yang terdapat pada mata pelajaran mengakibatkan berkembangnya media praktik pada sekolah kejuruan. Dengan ketidak tersediaaan media praktik yang sesuai dengan kurikulum untuk mengaplikasikan materi tentang mikrokontroler, maka proses pembelajaran akan dirasakan kurang optimal. Hal ini akan mengakibatkan siswa menjadi kesulitan dalam mengaplikasikan materi yang telah diberikan guru sehingga pemahaman siswa terhadap materi pembelajaran teknik mikrokontroler hanya terbatas pada materi saja tidak mendapatkan praktik. Harapannya jika siswa diberikan media praktik dapat menggambarkan peralatan sebenarnya yang akan mengakibatkan timbul stimulus dan motivasi dalam belajar untuk meningkatkan hasil belajar serta menjadikan prose pembelajaran komunikasi dua arah. Menurut Wiliam H. Burto (dalam Syaiful Sagala,2003) pembelajaran adalah upaya memberikan stimulus, bimbingan pengarahan, dan dorongan kepada siswa agar terjadi proses belajar. Untuk itu pada penelitian di SMK Negeri 4 Jurusan Teknik Elektronika yang sudah menggunakan kurikulum 2013 media praktik sangat dibutuhkan dengan mengikuti perkembangan.

Menurut Sudriman N. (1992) fase dalam metode pembelajaran ceramah adalah : (a) menyampaikan tujuan dan memotivasi siswa, (b) menjelaskan materi pembelajaran, (c) mengecek pemahaman siswa dan memberikan umpan balik, (d) melakukan rangkuman hasil pembelajaran. Menurut Kemp dan Dayton Arsyad (2014) media pembelajaran memenuhi tiga fungsi utama yaitu: (1) memotivasi minat atau tindakan, (2) menyajikan informasi, dan (3) memberi instruksi. Sedangkan menurut Levied an Lentz Arsyad (2014) fungsi media pembelajaran ada 
4 yaitu: (1) fungsi atensi, (2) fungsi afektif, (3) fungsi kognitif, dan (4) fungsi kompensatoris. Menurut Hamalik (1989), penggunaan media pembelajaran dalam proses pembelajaran sangat penting karena penggunaan media pembelajaran dalam proses pembelajaran dapat membangkitkan motivasi dan rangsangan kegiatan belajar siswa.

Oleh karena itu, guru perlu mempelajari bagaimana memilih dan memanfaatkan media pembelajaran agar dapat mengefektifitaskan pencapaian tujuan pembelajaran dalam proses belajar mengajar. Menurut Santoso, Slamet, Utami, \& Wulandari (2016), tujuan yang dicapai bersifat behavioral atau berbentuk tingkah laku yang dapat diamati dan diukur, yang semuanya itu harus dicapai dengan suatu strategi dimana kegiatan pembelajaran dilaksanakan dengan kondisi yang diciptakan secara sistematis, seperti mengintegrasikan komponen metode, sarana prasarana, media, dan lainnya, sehingga peserta didik mudah dalam mencapai tujuan pembelajaran yang telah ditetapkan. Pada proses di lapangan, media pembelajaran masih sering terabaikan dengan alasan sulit mencari media yang tepat dan biaya yang mahal. Seharusnya hal ini tidak perlu terjadi, jika guru mempunyai pengetahuan dan keterampilan mengenai materi dan media pembelajaran.

Menurut Hasan (2013) trainer merupakan suatu set peralatan di laboratorium yang digunakan sebagai media pendidikan yang merupakan gabungan antara model kerja dan mock-up. Triner merupakan benda nyata yang digunakan untuk mengaplikasikan materi pengetahuan/konsep pada proses pembelajaran. Tujuan utama trainer sebagai media praktik di sekolah adalah agar siswa mudah dan dapat memahami skema rangkaian elektronika baik secara hardware maupun software.

Mikrokontroler adalah suatu sistem komputer yang dirancang untuk keperluan pengontrolan sistem. Mikrokontroler dilengkapi dengan CPU sebagai unit pemrosesan pusat, memori dan perangkat perantara lainnya sehingga sering disebut mikrokomputer. Beda dengan sistem komputer yang mampu mengelola kata, mengelola angka dan menangani berbagai macam program aplikasi, mikrokontroler hanya mampu menyimpan suatu aplikasi tertentu saja. Mikrokontroler yang digunakan dalam pembuatan alat ini adalah produksi Atmel

Febriana Suryania, Moch.Sukardjo, M.Yusro Perancangan Trainer Mikrokontroler Sebagai Media Pembelajaran Untuk Meningkatkan Nilai Pada Mata Pelajaran Perekayasaan Sistem Kontrol Pada SMK 
dengan generasi AVR. Mikrokontroler AVR Atmega 8535 adalah salah satu dari keluarga Atmega dengan populasi pengguna cukup besar. AVR mempunyai 32 register general - purpose, timer/counter fleksibel dengan mode compare, interrupt internal dan eksternal, serial UART, programmable Watchdog Timer, dan mode power saving. AVR mempunyai In-System Programmable Flash on-chip yang berfungsi untuk mengulang program dalam system dan beberapa AVR memiliki ADC dan PWM internal.

Menurut Wardhana (2007) mikrokontroler AVR ATmega8535 merupakan IC yang memiliki fitur sangat lengkap karena memiliki arsitektur RISC (Reduced Instruction Set Computing) 8 bit, dimana instruksi kode 16 bit word dan instruksi dalam satu siklus clock dibandingkan dengan mikrokontroler MCS51 seperti 89C51/89C52 yang membutuhkan 12 siklus clock untuk mengeksekusi instruksi.

Konfigurasi dari gambar pin ATmega8535 dapat dijelaskan secara fungsional sebagai berikut : (Wardhana, 2007)

\begin{tabular}{|c|c|c|c|c|}
\hline & & & & \\
\hline (XCK/TO) PBO 미 & 1 & 40 & 曰 PAO & $(A D C 0)$ \\
\hline (T1) PB1 ᄃ & 2 & 39 & $\sqsupseteq$ PA1 & (ADC1) \\
\hline (INT2/AIN0) PB2 口 & 3 & 38 & 口 PA2 & $(A D C 2)$ \\
\hline (OC0/AIN1) PB3 Б & 4 & 37 & ص PA3 & $(A D C 3)$ \\
\hline (5S) PB4 므 & 5 & 36 & 曰 PA4 & (ADC4) \\
\hline (MOSI) PB5 무 & 6 & 35 & 曰 PA5 & (ADC5) \\
\hline (MISO) PB6 口 & 7 & 34 & $\sqsupseteq$ PA6 & (ADC6) \\
\hline (SCK) PB7 口 & 8 & 33 & 曰 PA7 & (ADC7) \\
\hline$\overline{\mathrm{RESET}}$ 口 & 9 & 32 & 口 AREF & \\
\hline VCC $\square$ & 10 & 31 & 口 GND & \\
\hline GND ם & 11 & 30 & $\sqsupseteq$ AVCO & \\
\hline XTAL2 무 & 12 & 29 & 曰 PC7 & (TOSC2) \\
\hline XTAL1 믄 & 13 & 28 & 口 PC6 & (TOSC1) \\
\hline (RXD) PDO 므 & 14 & 27 & $\square$ PC5 & \\
\hline (TXD) PD1 口 & 15 & 26 & $\sqsupseteq$ PC4 & \\
\hline (INT0) PD2 口 & 16 & 25 & $\sqsupseteq$ PC3 & \\
\hline (INT1) PD3 ㅁ & 17 & 24 & $\sqsupseteq$ PC2 & \\
\hline (OC1B) PD4 口 & 18 & 23 & $\sqsubseteq \mathrm{PC} 1$ & (SDA) \\
\hline (OC1A) PD5 ㅁ & 19 & 22 & $\sqsupseteq \mathrm{PCO}$ & (SCL) \\
\hline (ICP1) PD6 므 & 20 & 21 & 口 PD7 & $(\mathrm{OC} 2)$ \\
\hline
\end{tabular}

\section{Gambar 1 Konfigurasi Pin ATmega8535}

Sumber Buku Belajar Sendiri Mikrokontroller AVR Seri ATMega8535 Simulasi, Hardware, dan Aplikasi 
1. VCC merupakan pin yang berfungsi sebagai pin masukan catu daya

2. GND merupakan pin ground

3. PORT A (PA0 - PA7) merupakan I/O dua arah dan pin masukan ADC

4. PORT B (PB0 - PB7) merupakan I/O dua arah dan pin fungsi khusus, yaitu Timer/Counter, komparator analog, dan SPI

5. PORT C (PC0 - PC7) merupakan pin I/O dua arah dan pin fungsi khusus, yaitu TWI, komparator analog, dan Timer Oscilator

6. PORT D (PD0 - PD7) merupakan pin I/O dua arah dan pin fungsi khusus, yaitu komparator analog, interupsi eksternal, dan komunikasi serial

7. Reset merupakan pin yang digunakan untuk me-reset mikrokontroler

8. XTAL 1 dan XTAL 2 merupakan pin masukan clock eksternal

9. AVCC merupakan pin masukan tegangan untuk ADC

10. AREF merupakan pin masukan tegangan refrensi ADC

Proses kegiatan pembelajaran pada kurikulum 2013, keterampilan membutuhkan berbagai bentuk alat - alat bantu, sarana, dan fasilitas yang digunakan untuk menunjang proses belajar - mengajar dan dapat menyajikan berbagai bentuk informasi yang dibutuhkan secara lengkap. Alat bantu, sarana, dan fasilitas belajar merupakan bagian dari media pembelajaran yang dapat menimbulkan perhatian, pikiran, perasaan, dan minat siswa dalam kegiatan belajar agar tercapainya tujuan pembelajaran. Pencapaian tujuan pembelajaran diperlukan untuk meningkatkan efektivitas pengajaran baik secara materi maupun strategi. Namun, pada praktik di lapangan, permasalahan muncul pada proses pencapaian tujuan pembelajaran, dapat berasal dari faktor pengajar, sarana prasarana maupun siswa itu sendiri. Salah satu untuk meminimalisir permasalahan - permasalahan yang terjadi perlu melakukan pengembangan media pembelajaran.

Dalam proses pemilihan media pembelajaran diperlukan pengamatan lapangan guna untuk mengetahui kondisi serta fasilitas sarana dan prasarana yang ada. Hal ini dikarenakan, pengembangan media pembelajaran menggunakan perangkat keras butuh persiapan yang lebih matang baik dari segi kebutuhan maupun dari segi kemampuan guru.

Febriana Suryania, Moch.Sukardjo, M.Yusro Perancangan Trainer Mikrokontroler Sebagai Media Pembelajaran Untuk Meningkatkan Nilai Pada Mata Pelajaran Perekayasaan Sistem Kontrol Pada SMK 
Pada kurikulum di SMK kelas XII mengacu pada uji kompetensi kejuruan sebagai nilai akhir ujian praktikum. Menurut Samsudi (2009) studi tentang kesiapan SMK dalam UKK dalam ujian nasional ini mencakup kajian tentang: (a) kesiapan masukan dasar yang ada (tempat, guru, asesor, alat, dan bahan) dalam pelaksanaan UKK; (b) pelaksanaan UKK berkaitan dengan prosedur, tempat dan waktu penyelenggaraan; (c) pola pelaksanaan UKK dengan biaya yang terjangkau di SMK dan diakui oleh DU/DI.

Media yang akan diteliti bersumber dari kurangnya kesiapan sekolah dalam sarana prasarana untuk membantu siswa dalam proses belajar untuk mengikuti uji kompetensi kejuruan. Maka, untuk itu peneliti merancang media pembelajaran berupa trainer mikrokontroler sebagai alternative kegiatan belajar mengajar. Dengan melakukan penelitian diharapkan media dapat di implementasi dan digunakan sebagai pengembangan media pembelajaran, peneliti akan mencari tingkat kelayakan dan efektifitas media yang telah dirancang.

Berdasarkan latar belakang dengan permasalahann yang ada, maka perlu adanya fokus penelitian yang akan dikaji. Fokus penelitian ini adalah :

1. Pengembangan media pembelajaran berupa trainer mikrokontroler.

2. Pengembangan media pembelajaran mikrokontroler meliputi perangkat pembelajaran seperti : modul, RPP, instrumen penelitian yang dibuatkan untuk menguji validitas media pembelajaran, serta evaluasi untuk mengetahui efektifitas media pembelajaran.

Manfaat yang diharapkan dari penelitian ini adalah sebagai berikut:

1. Hasil penelitan ini diharapkan dapat digunakan sebagai media pembelajaran yang menunjang kegiatan belajar mengajar dalam melakukan proses praktikum.

2. Hasil penelitian ini diharapkan siswa mampu memahami dan memperdalam proses cara kerja dari trainer mikrokontroler.

\section{METODE}

Metode yang digunakan pada penelitian dan pengembangan media adalah ADDIE. Pengembangan trainer didasarkan pada hasil studi pendahuluan dan studi 
lapangan. Langkah - langkah penelitian dan pengembangan dilakukan mengacu pada hasil langkah sebelumnya hingga diperoleh suatu produk pendidikan yang baru. Alasan lain dari penggunaan penelitian dan pengembangan dari pendekatan ini dipandang tepat karena model pembelajaran ini bertujuan tidak hanya sekedar menemukan profil implementasi atau praktik - praktik pembelajaran yang efektif dan efesien melainkan menyesuaikan kondisi dan kebutuhan nyata di sekolah.

Menurut Anglada (2007), penelitian dan pengembangan yang digunakan di ADDIE yaitu analisis, desain, pengembangan, implementasi dan evaluasi. Tahap analisis meliputi kegiatan sebagai berikut: (a) melakukan analisis kompetensi yang dituntut kepada siswa; (b) melakukan analisis karakteristik siswa tentang kapasitas belajarnya, pengetahuan, keterampilan, sikap yang telah dimiliki siswa serta aspek lain yang terkait; (c) melakukan analisis materi sesuai dengan tuntutan kompetensi. Tahap desain adalah tahapan yang perlu dilaksanakan pada proses perancangan untuk merumuskan tujuan pemebelajaran yang spesifik, measurable, applicable, dan realistic. Tahap pengembangan adalah proses pengembangan produk sebagai penggunaan sistem. Tahap implement adalah langkah nyata untuk menerapkan sistem pembelajaran yang dikembangkan. Terakhir, tahap evaluasi adalah proses yang dilaksanakan sebagai bahan evaluasi untuk kebutuhan revisi.

Data yang dikumpulkan menggunakan instrumen penelitan seperti instrumen ahli media, instrumen ahli materi, dan instrumen untuk siswa. Instrumen ini sebelumnya telah divalidasi oleh validator untuk mengetahui keabsahan materi yang akan dijadikan butir instrument. Butir soal tersebut dibuatkan kisi - kisi soal untuk memudahkan validator dan peneliti dalam membuat instrumen.

Teknik analisis data yang digunakan adalah statistik deskriptif kualitatif yang digunakan untuk menganlisa data dengan cara mendeskripsikan atau menggambarkan data yang telah terkumpul.

1) Kuisioner

Data kuisioner diperoleh dari hasil validasi ahli materi dan ahli media, ujicoba satu - satu, ujicoba kelompok kecil dan ujicoba lapangan kemudian diolah menggunakan skala Likert yaitu skala 4. Hasil penilaian setiap

Febriana Suryania, Moch.Sukardjo, M.Yusro Perancangan Trainer Mikrokontroler Sebagai Media Pembelajaran Untuk Meningkatkan Nilai Pada Mata Pelajaran Perekayasaan Sistem Kontrol Pada SMK 
komponen media pembelajaran berupa trainer dengan menggunakan rumus

$$
\bar{X}=\frac{\sum x}{n}
$$

Keterangan :

$$
\begin{aligned}
& \bar{X}=\text { Skor rata }- \text { rata } \\
& \mathrm{N}=\text { Jumlah penilai } \\
& \sum x=\text { Skor masing }- \text { masing penilai }
\end{aligned}
$$

Tabel 1 Tabel Validasi Penelitian

\begin{tabular}{ccc}
\hline NO. & Skor Presentase (\%) & Interpretasi \\
\hline 1. & $0-25$ & Tidak Layak \\
\hline 2. & $>25-50$ & Kurang Layak \\
\hline 3. & $>50-75$ & Layak \\
\hline 4. & $>75-100$ & Sangat Layak \\
\hline
\end{tabular}

Perencanaan pengembangan model dibuat dan disesuaikan dengan kebutuhan trainer yang sesuai dengan kurikulum. Karakteristik dari trainer yang akan dibuat meliputi :

a. Sumber tegangan : Tegangan yang digunakan 12 VDC yang akan dikoneksikan ke terminal blok

b. Interfacing : berupa downloader ISP yang akan digunakan untuk membantu memindahkan program ke dalam hardware

c. Input : berupa masukan yang terdiri dari push button, keypad, dan DIP switch

d. Proses : berupa mikrokontroler ATMega8535 yang digunakan untuk mengontrol program

Output : berupa keluaran yang terdiri dari LED, LCD, seven segment, Motor

Dc, Motor Stepper, Buzzer, dan Dot Matrik.

Proses pembuatan :

1. Membuat gambar rancangan mekanik.

2. Mebuat gambar rancangan layout PCB.

3. Mencetak PCB dengan bantuan mesin sablon.

4. Menyolder komponen yang dibutuhkan

5. Melakukan pengujian alat

JINoP (Jurnal Inovasi Pembelajaran),Volume 5, Nomor 2, November 2019, hal 123-138 


\section{HASIL DAN PEMBAHASAN}

Hasil dari penelitian ini melihat seberapa efektif media pembelajaran berupa trainer mikrokontroler dalam pengaplikasian di SMK untuk mata pelajaran perekayasaan sistem kontrol. Pada penelitian pendahulu yang dilakukan oleh Setyawan \& Bambang (2013) pada jurnalnya masih menggunakan IC At89s51 yang dapat mengeksekusi satu intruksi dengan 12 clock, bahasa pemrograman yang digunakan cukup rumit dan memiliki memori internal yang sangat kecil yaitu $4 \mathrm{~Kb}$.

Maka, penelitian kali ini akan membuat trainer mikrokontroler yang sesuai dengan baik siswa maupun perkembangan kurikulum. Pada tahapan ini dilakukan 2 kegiatan utama, yaitu: (1) kegiatan validasi dan (2) melakukan ujicoba lapangan. Penelitian ini menggunakan dua tahap dalam menguji kelayakan produk yaitu dengan validitas teori dan validitas empirik.

Validitas teoritik didapat dari validasi dan evaluasi oleh para ahli (expert judgment) untuk menilai kelayakan media pembelajaran yang dikembangkan. Penilaian ini akan menjadi dasar untuk memperbaiki media pembelajaran yang dinilai kurang baik oleh para ahli. Para ahli yang menilai pada media pembelajaran ini memiliki latar belakang keahlian dalam bidang media pembelajaran dan materi tentang perekayasaan system kontrol. Validiator media dilakukan oleh pakar dibidang teknologi pendidikan, sedangkan untuk validator materi dilakukan oleh dosen yang ahli dibidang elektronika. Evaluasi dilakukan melalui kuisioner untuk mengetahui pendapat para ahli tentang kualitas media pembelajaran berupa trainer yang sudah dikembangkan. Hasil penilaian ahli materi pada media pembelajaran mendapatkan skor rata - rata 3,83 yang berarti program ini dinilai baik.

Tabel 2 Hasil Penilaian oleh Ahli Materi

\begin{tabular}{clc}
\hline No. & \multicolumn{1}{c}{ Aspek } & Rerata \\
\hline 1 & Kelayakan Isi & 3.9 \\
\hline 2 & Kelayakan Penyajian & 3.8 \\
\hline 3 & Penilaian & 3.8 \\
\hline \multicolumn{2}{c}{ Jumlah } \\
\hline
\end{tabular}

Secara rinci pada tabel 2 hasil penilaian dari masing - masing aspek dan indikator diuraikan sebagai berikut : Pada aspek kelayakan isi terdapat indikator

Febriana Suryania, Moch.Sukardjo, M.Yusro Perancangan Trainer Mikrokontroler Sebagai Media Pembelajaran Untuk Meningkatkan Nilai Pada Mata Pelajaran Perekayasaan Sistem Kontrol Pada SMK 
yang mendapatkan skor 3,9 yang meliputi beberapa indikator, sedangkan kelayakan penyajian mendapatkan skor 3,8 dan penilaian mendapatkan skor 3,8. Penilaian dari aspek materi sudah dapat dikategorikan baik dalam pelakasanaannya.Hasil penilaian untuk ahli media pembelajaran, mendapatkan skor rata - rata 3.47 berati program dinilai baik. Berikut ini hasil penilaian ahli media.

Tabel 3 Hasil Penilaian oleh Ahli Media

\begin{tabular}{lll} 
NO. & Aspek & Rerata \\
\hline 1 & Ukuran Trainer & 3 \\
\hline 2 & Desain dan Tata Letak Trainer & 3.4 \\
\hline 3 & Penyajian Pembelajaran & 4 \\
\hline Jumlah & & 3.47 \\
\hline
\end{tabular}

Secara rinci pada tabel 3 hasil penilaian dari masing - masing aspek dan indikator dijabarkan sebagai berikut :

Pada indikator ukuran mendapatkan skor 3 yaitu kesesuaian ukuran, tools yang digunakan, dan kesesuaian ukuran. Pada indikator desain dan tata letak mendapatkan skor 3.4 sedangkan untuk penyajian pembelajaran mendapatkan skor 4.

Dalam penelitian ini untuk melaksanakan validitas empiris dilakukan dengan :

a) Uji Coba dan Evaluasi Satu-Satu (One to One Evaluation)

Setelah dilakukan revisi berdasarkan hasil evaluasi dan masukan dari para ahli, langkah selanjutnya dari proses pengembangan ini adalah melakukan uji coba satu - satu kepada siswa kelas XII TEI. Uji coba ini dimaksudkan untuk mengetahui kelayakan media pembelajaran secara empirik. Uji coba dilakukan terhadap 3 orang siswa kelas XII TEI. Pengembang meminta siswa untuk memberikan komentar dengan lelusa tentang media pembelajaran. Siswa diminta mencatat, mengamati, mencermati dan mendiskusikan media pembelajaran yang sedang mereka pelajari.

JINoP (Jurnal Inovasi Pembelajaran),Volume 5, Nomor 2, November 2019, hal 123-138 
Evaluasi dilakukan melalui kuisioner dengan melihat aspek tampilan, penyajian materi, dan manfaat. Data yang diperoleh melalui penyebaran kuisioner dapat digambarkan sebagai berikut :

Tabel 4 Hasil Penilaian Uji Coba Satu - satu

\begin{tabular}{lll}
\hline No. & Aspek & Rata - rata \\
\hline 1. & Tampilan & 3.0 \\
\hline 2. & Penyajian materi & 3.1 \\
\hline 3. & Manfaat & 3.0 \\
\hline & Jumlah Rata - rata & 3.03 \\
\hline
\end{tabular}

Secara umum pada tabel 4 tahap uji coba satu - satu diperoleh hasil bahwa media pembelajaran yang dikembangkan dapat dikatakan baik dengan rata - rata nilai keseluruhan 3,03. Selain itu, data dari masing - masing aspek dan indikator yang dinilai dapat diuraikan sebagai berikut :

Terkait dengan aspek tampilan mendapatkan skor rata - rata 3,0 nilai berada pada dikategori baik. Dimana pada indikator tampilan mendapat skor rata - rata 3,0 .

Pada aspek penyajian materi,secara keseluruhan mendapatkan skor rata - rata 3,1 yang berada pada kategori baik. Sedangkan pada aspek manfaat mendapatkan skor rata - rata 3,0 yang berada pada kategori baik.

b) Uji Coba dan Evaluasi Kelompok Kecil (Small Group)

Setelah dilakukan revisi terhadap masukan dan saran dari uji coba satu satu, maka dilakukan uji coba kelompok kecil. Uji coba ini bertujuan untuk menggali informasi dan masukan dari siswa mengenai media pembelajaran dan menekankan pada kejelasan dan keefektifan setiap aspek pada media pembelajaran, yaitu aspek tampilan, aspek penyajian materi, dan manfaat mengenai kejelasan indikator pembelajaran, rata - rata siswa memahami maksud dari indikator yang dinyatakan dalam media pembelajaran dan mengetahui kemampuan yang mereka dapat setelah mempelajari materi pelajaran.

Uji coba dilakukan pada 8 orang siswa perekayasaan sistem kontrol kelas XII TEI, setelah itu diminta untuk mengisi kuisioner mengenai media pembelajaran yang mereka gunakan.

Febriana Suryania, Moch.Sukardjo, M.Yusro Perancangan Trainer Mikrokontroler Sebagai Media Pembelajaran Untuk Meningkatkan Nilai Pada Mata Pelajaran Perekayasaan Sistem Kontrol Pada SMK 
Secara umum pada tahap uji coba kelompok kecil diperoleh hasil bahwa media pembelajaran yang dikembangkan dapat dikatakan baik dengan rata - rata keseluruhan 3,46. Data yang diperoleh melalui penyebaran kuisioner pada uji coba kelompok kecil dapat digambarkan sebagai berikut:

Tabel 5 Hasil Penilaian Uji Coba Kelompok Kecil

\begin{tabular}{lll}
\hline No. & Aspek & Rata - rata \\
\hline 1. & Tampilan & 3.4 \\
\hline 2. & Penyajian materi & 3.5 \\
\hline 3. & Manfaat & 3.5 \\
\hline & Jumlah Rata - rata & 3.46 \\
\hline
\end{tabular}

Pada aspek tampilan, secara keseluruhan pada tabel 5 mendapatkan skor rata - rata 3.4, nilai ini berada pada kategori baik. Sedangkan, skor rata - rata penyajian materi mendapatkan skor 3.5 nilai ini berada pada kategori baik dan aspek manfaat mendapatkan skor 3.5 berada pada kategori baik.

c) Uji Coba Lapangan

Setelah dilakukan revisi berdasarkan masukan dan saran uji coba sebelumnya, maka dilakukan uji coba lapangan yang bertujuan untuk menggali informasi dan masukan dari siswa mengenai media pembelajaran dan dapat mengetahui keefektifan setiap aspek pada media pembelajaran perekayasaan sistem kontrol. Uji coba dilakukan pada 31 siswa kelas XII TEI. Siswa diminta untuk mengisi kuisioner yang diberikan pada saat uji lapangan.

Secara umum skor yang diperoleh mendapatkan rata - rata 3,6, nilai ini dikategorikan baik. Adapun hasil yang didapat pada tabel 4.6 uji lapangan :

Tabel 6 Hasil Penilaian Uji Lapangan

\begin{tabular}{lll}
\hline No. & Aspek & Rata - rata \\
\hline 1. & Tampilan & 3.7 \\
\hline 2. & Penyajian materi & 3.6 \\
\hline 3. & Manfaat & 3.5 \\
\hline & Jumlah Rata - rata & 3.6 \\
\hline
\end{tabular}

Pada uji coba lapangan dilakukan untuk mengetahui efektifitas media pembelajaran perekayasaan sistem kontrol yang dikembangkan. Efektifitas diukur dengan kuisioner untuk mendapatkan pendapat siswa mengenai media pembelajaran perekayasaan sistem kontrol menganalisis hasil belajar (pretest dan

JINoP (Jurnal Inovasi Pembelajaran),Volume 5, Nomor 2, November 2019, hal 123-138 
posttest) pada ranah kognitif dan psikomotorik (posttest) dengan menerapkan skor minimum pencapaian kompetensi sebesar 75 (tujuh puluh lima).

Uji coba dilakukan terhadap 31 orang siswa yang belum mendapatkan materi perekayasaan sistem kontrol. Uji coba dilakukan melalui langkah - langkah berikut : sebelum diberi penjelasan mengenai materi pembelajaran dengan menggunakan media, siswa diberikan pretest. Siswa diminta untuk menjawab beberapa pertanyaan yang ada pada lembar soal. Hasil dari pretest mengindikasikan bahwa materi pelajaran benar - benar dibutuhkan oleh siswa untuk menambah pemahaman dan pengetahuan tentang perekaysaan sistem kontrol. Informasi ini dapat disimpulkan dari skor yang didapatkan oleh 31 siswa yang mengikuti pretest untuk menilai ranah kognitif ini mendapatkan skor rata - rata 50,96 dari skor tertinggi 100. Pencapaian angkai ini dapat dikategorikan rendah.

Setelah mengerjakan pretest, siswa diberi penjelasan untuk selanjutnya mengikuti pembelajaran dengan menggunakan media pembelajaran perekayasaan sistem kontrol. Materi perekayasaan sistem kontrol dengan bantuan laptop/komputer untuk operasi dan jobsheet sebagai buku panduan soal pengerjaan yang diberikan pada masing - masing siswa.

Siswa diberikan waktu 5 kali pertemuan dengan masing - masing $3 \times 45$ menit untuk mempelajari setiap pokok bahasan yang terdapat pada media pmebelajaran dan mengerjakan soal latihan. Pada pertemuan ke 6, siswa diminta untuk mengerjakan posttest baik secara kognitif maupun psikomotorik, serta kuisioner sebagai bahan penilaian. Dari hasil posttest untuk ranah kognitif didapatkan skor rata - rata 76,54 dan hasil posttest untuk menilai ranah psikomotorik didapatkan nilai rata - rata 85. Pencapaian angka ini dapat dikategorikan baik dan dapat menunjukan peningkatan hasil belajar setelah menggunakan media pembelajaran berupa trainer dan dapat menambah wawasan siswa dalam pembuatan program dasar.

Pada pengujian signifikansi dengan menggunakan uji-t, penilaian pretest dan posttest ranah kognitif menunjukan hasil $t_{\text {hitung }}=0,17$ sedangkan untuk $t_{\text {tabel }}=2,042$. Dapat disimpulkan $\mathrm{H}_{0}$ diterima, bahwa pembelajaran perekayasaan sistem kontrol

Febriana Suryania, Moch.Sukardjo, M.Yusro Perancangan Trainer Mikrokontroler Sebagai Media Pembelajaran Untuk Meningkatkan Nilai Pada Mata Pelajaran Perekayasaan Sistem Kontrol Pada SMK 
dengan menggunakan media pembelajaran berupa trainer mikrokontroler ini efefktif dalam pencapaian kompetensi siswa.

\section{SIMPULAN}

Berdasarkan hasil penelitian yang diperoleh dari penelitian dan pengembangan media pembelajaran trainer mikrokontroler maka dapat disimpulkan sebagai berikut: Pertama, proses penelitian dan pengembangan yang dilaksanakan telah menghasilkan media pembelajaran berupa trainer mikrokontroler. Prosedur pengembangan media pembelajaran trainer terdiri dari langkah - langkah sebagai berikut: Penelitian dan mengumpulkan data yaitu termasuk analisis kebutuhan, mengobservasi, studi literatur yang berkaitan dengan teori dan konsep pembelajaran. Perencanaan pengembangan media pembelajaran berupa trainer mikrokontroler dengan menyusun rencana penelitian, meliputi merumuskan tujuan yang ingin dicapai dan merancang desain dan membuat analisis. Melakukan uji coba dan evaluasi produk untuk mengetahui kelemahan kelemahan dari produk. Melalui kegiatan evaluasi ini telah diperbaiki sejumlah kelemahan produk, baik yang menyangkut aspek media dan aspek materi. Evaluasi dilakukan secara bertahap yaitu dimulai dari kaji ahli (expert judgment), evaluasi satu-satu (one to one), evaluasi kelompok kecil (small group), dan evaluasi uji lapangan untuk melihat efektifitas media pembelajaran berupa trainer mikrokontroler.

Kedua, untuk mengetahui efektifitas media pembelajaran berupa trainer mikrokontroler dilakukan uji lapangan dengan cara menganalisis hasil pretest dan posttest. Berdasarkan hasil uji coba lapangan terhadap 31 siswa kelas XII TEI, terlihat perbedaan hasil tes belajar yaitu pretes dengan nilai paling rendah adalah 33 dan nilai tertinggi 62 . Sedangkan hasil posttes memperoleh nilai paling rendah 59 dan nilai tertinggi 89. Jika dibandingkan hasil pretes dan posttes terhadap peningkatan hasil belajar. Selain itu, berdasarkan analisis data diatas terlihat hasil $t_{\text {hitung }}=0,17$ sedangkan untuk tabel $=2,042$. Dapat disimpulkan $\mathrm{H}_{0}$ diterima, bahwa pembelajaran perekayasaan sistem kontrol dengan menggunakan media 
pembelajaran berupa trainer mikrokontroler ini efefktif dalam pencapaian kompetensi siswa.

Berdasarkan hasil penelitian dan kesimpulan yang telah diuraikan, maka media pembelajaran berupa trainer mikrokontroler ini akan berimplikasi pada beberapa hal, diantaranya: Pertama, media pembelajaran berupa trainer ini dapat diimplementasikan sebagai salah satu media alternatife dalam mempelajari mata pelajaran perekayasaan sistem kontrol. Penggunaan media pembelajaran dapat membantu siswa dalam meningkatkan kompetensi yang dimilikinya. Kedua, implikasi dari pengembangan ini terhadap siswa kelas XII TEI terutama untuk mata pelajaran perekayasaan sistem kontrol adalah untuk di perlakukan dukungan dan kesiapan pihak sekolah untuk memperbanyak dan mengintegrasikan media pembelajaran berupa trainer mikrokontroler di dalam perkuliahan sehingga dapat menjadi alternative sumber belajar mata pelajaran perekayasaan sistem kontrol. Ketiga, Bagi guru di jurusan TEI, media pembelajaran berupa trainer mikrokontroler ini dapat diintegrasikan dan diterapkan baik untuk pelajaran yang sedang berjalan, maupun untuk pelajaran ke depannya nanti dengan siswa baru. Penggunaan media pembelajaran berupa trainer mikrokontroler dapat diintegrasikan dengan pembelajaran di kelas dengan menjelaskan aturan yang dapat disepakati bersama terlebih dahulu.

\section{DAFTAR PUSTAKA}

Anglada, D. (2007). $\|$ An Introduction to Instructional Design: Utilizing a Basic Design Modell. Http://Www.Pace.Edu/Ctlt/Newslette.

Arsyad, A. (2014). Media Pembelajaran. Jakarta: Raja Grafindo Persada.

Hamalik, O. (1989). Media Guruan. Bandung: PT. Citra Aditya Bakti.

Hasan, S. (2013). Analisis Perakitan Trainer Unit Berdasarkan Aplikasi Konsep Refrigerasi Pada Mata Kuliah Sistem Pendingin. Journal of Chemical Information and Modeling, 53(9), 1689-1699. https://doi.org/10.1017/ CBO9781107415324.004

Kurnia Setyawan, B., \& Bambang Poerwantono. (2013). Pembuatan Trainer Dan Modul Mikrokontroler Untuk Standar Kompetensi Pengendali

Febriana Suryania, Moch.Sukardjo, M.Yusro Perancangan Trainer Mikrokontroler Sebagai Media Pembelajaran Untuk Meningkatkan Nilai Pada Mata Pelajaran Perekayasaan Sistem Kontrol Pada SMK 
Elektromagnetik Dan Elektronika Di Smk Negeri 3 Buduran Sidoarjo. Jurnal Pendidikan Teknik Elektro, 2(2), 445-449.

Samsudi, S. (2009). Kesiapan Sekolah Menengah Kejuruan Dalam Pelaksanaan Uji Kompetensi Dalam Rangka Ujian Nasional. Teknologi Dan Kejuruan: Jurnal Teknologi, Kejuruan Dan Pengajarannya, 32(2).

Santoso, D., Slamet, S., Utami, P., \& Wulandari, B. (2016). Pengembangan Trainer Signal Conditioning. Jurnal Pendidikan Teknologi Dan Kejuruan, 13(1), 7384. https://doi.org/10.23887/jptk-undiksha.v13i1.6848

Sudriman N., dkk. (1992). Ilmu Pendidikan. Bandung: Remaja Rosdakarya.

Wardhana, L. (2007). Belajar Sendiri Mikrokontroler AVR Seri ATMega8535 Simulasi, Hardware, dan Aplikasi. Yogyakarta: Penerbit Andi. 